Rev. Bogustaw Kieżel Archidiecezjalne Wyższe Seminarium Duchowne w Biatymstoku

\title{
Orishas in Cuban Santería According to Nelson Marcos Aboy Domingo
}

Santería (also called La Regla de Ocha, or The Rule of Ocha) is an Afro-American syncretic religion practiced in Cuba. At the center of this religion is a belief in the Supreme Being, in deity intercessors (Orishas), and ancestral spirits. Orishas are like divine mediators between the Supreme Being and men. They represent the embodiment of natural forces and natural phenomena such as birth and death, health and disease, rain and dew, and trees and rivers. Orishas represent the four great elements of nature: fire, water, earth and air, as well as the three dimensions of nature: mineral, vegetal, and animal. The Orishas are the emanations of the Supreme Being, from whom they have received divine attributes and characteristics. Their task is to help the Supreme Being to govern the world. This study presents the original concept of "Orisha" according to Nelson Marcos Aboy Domingo, the Cuban anthropologist and babalawo, by first presenting how the concept of orishas came about, and then examining the essence, function, and roles of Orishas as well as their cult in Cuban Santería according to concept of Cuban anthropologist.

Key words: Cuban Santería, Orishas, cult, African-American religions, Nelson Marcos Aboy Domingo.

\section{Introduction}

Santería (also called La Regla de Ocha) is a syncretic AfricanAmerican religion practiced in Cuba. According to some cultural 
anthropologists, ${ }^{1}$ the term "African-American religions" is imprecise because of the complex issues of popular religious practices in America, because of their content, and because the evolution, cults, and ceremonies of these religions are so varied. African-American religions have a rich African cultural heritage, which is considered a common good on the American continent. ${ }^{2}$ The traditional African beliefs of the Yoruba (in Cuba the Yoruba people are called "Lucumi," which comes from the response "oluku mi-my friend" to the Yoruba greeting), Ewe, Ibo, Efik, and Bakongo (in Cuba, "Congo") people are the source of Santería in Cuba. ${ }^{3}$ Diego Velázquez brought the aforementioned African peoples to Cuba as slaves when conquered the island at the end of 1510 or the beginning of $1511 .{ }^{4}$ During the salve trade in the nineteenth century, 550 thousand slaves were transported from Africa to Cuba, which is more than $35 \%$ of all of the slaves brought from Africa to Spanish-speaking America during the years 1451-1870. ${ }^{5}$

The African people brought with them their own culture, traditions, and beliefs. Cuba, therefore, provided a new environment and conditions for the rich African religious traditions to grow. However, the Spanish colonial society in which Africans found themselves followed the Christian faith. For this reason, many slave owners required their slaves to receive Christian baptism. But, the cultural values and religions that influenced African life on what was known as the Dark Continent caused new challenges and difficulties in Cuba. Due to Christian evangelization in Cuba, belief in the Supreme Being, in deities (Orishas), and ancestral spirits began to take on new forms, and African slaves began to worship Orishas, known as the deityintercessors between the Supreme Being and man, under the façade

$1 \quad$ J. Guanche, "Las religiones afroamericanas en América Latína y el Caribe ante los desafíos de internet," in América Latína y el Caribe. Territórios religiosos y desafios para el diálogo, ed. Aurelio Alonso (Buenos Aires: CLASCO, 2008), 278-279.

2 C.L. Cohen and R.L. Numbers, Eds., Gods in America:Religious Pluralism in the United States (New York: Oxford University Press, 2013), 3-18; L.G. Desmangles, The Faces of the Gods: Vodou and Roman Catholicism in Haiti (North Carolina: North Carolina U Press, 1992), 17-28.

T. Gadacz and B. Milerski, eds., "Santería," Religia. Encyklopedia PWN, Vol. 9 (Warsaw: Wydawnictwo PWN, 2003), 39.

J. Castellanos and I. Castellanos, Cultura afrocubana, Vol. 1 (Miami: Ediciones Universal, 1988), 19. 
of the Catholic saints most prevalent in Cuba at that time: the Mother of God and El Cobre, meaning St. Barbara.

The beginning of this paper will present issues related to the emerReliogiology gence and interpretation of the concept "Orisha" and then present the cult of Orishas in Cuban Santería according to Nelson Marcos Aboy Domingo, the Cuban anthropologist and highest priest (babalawo) in Santería. This article aims to present a new and different (from commonly accepted interpretations from the anthropology of religion) interpretation of the concept of "Orishas" in order to contribute to a better understanding of the complex phenomena of Afro-Cuban religious syncretism. For, religious syncretism in Latin America still has yet to be fully explained by science. Referring to the studies of J. E. Martins Terra ${ }^{6}$ Andrzej Pietrzak believes that "the usual justifications for this phenomenon point out that the superficial catechesis, survival strategies, the opposition of slaves, the powerful influence of African traditions and Iberian religiosity-particularly the cult of the saints and the brotherhood of slaves-do not ultimately explain the causes of religious syncretism in Latin America." In this article, we will also consider the answer to the question: According to Nelson M. Aboy Domingo, is there a path to salvation that serves as the end of and can be reached through Cuban Santería?

\section{The Formation of the Concept of "Orisha"}

The formation of the concept of "Orisha" has its own history. According to Pierre Verger, Samuel Ajayi Crowther-a slave from the ancient kingdom of Oyó (presently Nigeria)—was the first to sketch an image of the "Orisha." Baptized in London, Samuel Crowther published a translation of sections of the Bible into Yoruba in 1852. In his translation, he called Orishas "goddesses." The author of this work presented Oduduá as the goddess Ifê-the highest goddess of the world—while simultaneously pointing out that Obatalá is a great

6 J. E. Martins Terra, "Sincretismo e cristianismo," Revista de Cultura Biblica Vol. 33, no. 34 (1985).

$7 \quad$ A. Pietrzak, "Synkretyczne religie afrykańskie w Ameryce Łacińskiej," Dzieje kulturylatynoamerykańskiej, ed., M.F. Gawrycki (Warsaw: Wydawnictwo PWN, 2009), 260.

$8 \quad$ P. Verger, "Etnografia religiosa iorubá e probidade científica," Religião e Sociedade, no. 8 (Rio de Janeiro: 1982), 3-10. 
goddess. ${ }^{9}$ Consequently, Samuel A. Crowther made a distinction between goddesses and gods.

Similarly, an American Baptist missionary T. J. Bowen published a Yoruba dictionary in 1856. According to Pierre Verger, in this dictionary, T. J. Bowen precisely defined the concept of "Orishas." 10 The author states that the Orisha Obatalá has a place in the kingdom of Ifé and is the first of the created orishas. Pierre Bouche, a missionary from the Community of the African Missions in Lyons, France, published a book entitled La côte des esclaves et le Dahomey (The Slave Coast and Dahomey) in Paris in 1885. In this book, he shows the syncretic dimension of deities. He compares the goddess Iyangba with the Mother of God, but he does not point to the fact that the expression "Iya Àgba" is a euphemism for the greeting "İyámi Oxorongá."11

Noel Baudin's publication presents one big terminological mix-up concerning how to interpret the term "orisha." Father Noel Baudin was a French missionary who worked in Africa between 1869 and 1883 . Motivated by a desire to convert the people, Fr. Baudin published a glossary in $1884^{12}$ that led to the introduction of many terminological distortions of the word "orisha." ${ }^{13}$ Fr. Baudin wrote: "Witches are despicable, deceitful, lazy, false, shameless, beings. They are perfect thieves. [...] As for gods and goddesses with their whimsical legends, they are great witches. Do not believe in them. The idols look like the ugliest black man with huge lips, a flat nose, slender chin-they are true images of old monkeys." "According to Pierre Verger, Fr. Baudin unjustly combines and simultaneously confuses various deities such as Iyangba and Oduduá that do not even appear in the same ethnic group. ${ }^{15}$ Fr. Baudin also emphasizes that the deity Obatalá is a spirit, Oduduá is matter, Obatalá is the firmament of the Earth, and Oduduá is the Earth. ${ }^{16}$ Moreover, Fr. Baudin, interchangeably describes and

$9 \quad$ S.J. Crowther, A vocabulary of the yorubalanguage (London: Seeley, Fleet Street, 1852), 207, 223, in P. Verger, Etnografia religiosa iorubá e probidade científica, 4.

P. Verger, Notes sur le culte des orixá (Dacar: 1957), 171, 509.

P. Verger, Etnografia religiosa, 4.

N. Baudin, Dictionnaire français-yoruba et yoruba-français, $2^{\text {nd }}$ Edition (Cotonou: 1967).

13 P. Verger, Etnografia religiosa, 4.

14 N. Baudin, Dictionnaire français-yoruba, 86, in P. Verger, Etnografia religiosa, 4. Author's own translation.

Ibid. 
confuses the Yoruba Orishas with the Benin hydras, and the word égungun (skeleton bones) with the term exúngún (ancestral spirits). ${ }^{17}$

The aforementioned $19^{\text {th }}$ century interpretations of the word "Orisha" were followed by other interpretations by authors such as A. B. Ellis, who borrowed heavily from the terminology of Nina Rodrigues and Artur Ramos. ${ }^{18}$ Contemporary discrepancies in the interpretation of the Orishas' roles and functions also exist. For example, Pierre Verger points out that, by creating two categories of Orishas-male and female, Juan Elbein dos Santos, became the victim of his own "illusions" because elements attributed to male Orishas also appear in female Orishas. ${ }^{19}$ In addition, as Pierre Verger notes, dos Santos does not precisely define the terms "eshu," "ashe," and the relationship between the two words. ${ }^{20}$

Despite the differences in interpretation of the term "Orishas," their roles, and their functions, researchers now agree in principle that the Orisha worship refers to the forces of nature. ${ }^{21}$ This applies to both the Yorubas of Nigeria and the Benin. Although, the people from central and southern Benin (Fon and Ewe, respectively) worship deities that their people call "vodun (voodoo)." 22 The term "Orisha" is a general name for the Yoruba deities from Nigeria and Benin. In Africa, they number anywhere from 200-1,700. ${ }^{23}$ Generally speaking, they are referred to as deities that mediate between the Supreme Being and man. ${ }^{24}$ In Yoruba language, the etymology of the word "Orisha" comes

17

Ibid, 5 .

A. B. Ellis, The Yoruba Speaking Peoples of the Slave Coast of West Africa: Their Religion, Manners, Customs, Laws, Language, Etc. (London: Chapman and Hall, 1894); N. Rodrigues, Os Africanos no Brasil (Rio de Janeiro, 1934); A. Ramos, O negro brasileiro (São Paulo: 1940).

J. Elbein dos Santos, Os Nàgô e a morte. Pâde, Àsèsè e o culto Égun na Bahia, $8^{\text {th }}$ Edition (Petrópolis: 1997).

P. Verger, Etnografia religiosa, 5. Juana Elbein dos Santos responded to P. Verger's in in the following article: J. Elbein dos Santos, "Pierre Verger e os resíduos coloniais: o 'outro' fragmentado," Religião e Sociedade, no. 8 (Rio de Janeiro: ISER-CER, 1982), 11-14.

P. Verger, Notas sobre o culto aos orixas e voduns na Bahia de Todos os Santos, no Brasil, e na antiga Costa dos Escravos, na África (São Paulo: EDUSP, 1999), 35.

S.Piłaszewicz, Religie imitologia CzarnejAfryki:Przegladencyklopedyczny (Warsaw: Wydawnictwo Akademickie Dialog,2002), 245-246; See also: S. Piłaszewicz, Religie Afryki (Warsaw: Wydawnictwa Uniwersytetu Warszawskiego, 2000), 67.

S. Piłaszewicz, Religie i mitologia Czarnej Afryki, 188.

R. Bastide, The African Religions of Brazil: Toward a Sociology of the Interpenetration of Civilizations, trans. H. Sebba (Baltimore: John Hopkins University 
from the expression "Ibiti ori ti sè," which means "origin" or "source;" in this context, "ori" signifies "head" and "-sha" means "master" or "lord." Therefore, when taken together, the word "Orisha" means "the lord of the head," in the sense of the human person. The source or origin of the "head-human being" is the Supreme Being (Olódùmaré - the great Orí). Other terms used for the Yoruba deities are "rúnmalè" or "imalé, imolè," which mean "divine beings of the Earth."

While it is very difficult to count exactly how many different Orishas there are, a symbolic number of Orisha's exists. On the right side there are 400 irunmalè, and on the left side there are half that number, meaning 200 ébora. ${ }^{26}$ This is many Orishas. In addition to this number, there is always one (1) eshu that exists in both groups and serves as a link between the whole religious system by transmitting ashe in it. The mediation of Eshu in Orisha worship is inalienable; for, Eshu gives strength and power; it enlivens and transmits the essential sacred power called "ashe." ${ }^{27}$ Orishas represent the embodiment of the forces of nature and natural phenomena such as birth and death, health and disease, rain and dew, and trees and rivers. These deities also represent four great elements of nature: fire, water, earth, and air, as well as the three dimensions of nature: mineral, vegetal and animal. ${ }^{28}$ Orishas are emanations of the Supreme Being from whom they receive divine attributes and characteristics; as such, they help

Press, 1978); P. Verger, Notas sobre o culto aos orixás e voduns na Bahia de Todos os Santos, no Brasil, e na antiga Costa dos Escravos, na África, trans. C.E. Marcondes de Moura (São Paulo: Editora da Universidade de São Paulo, 1999); J. Elbein dos Santos, Os Nàgô e a morte. Pâde, Àsèsè e o culto Égun na Bahia, $8^{\text {th }}$ Edition(Petrópolis: Vozes, 1997); O.G. Cacciatore, Dicionário de cultos afro-brasileiros (Rio de Janeiro: Forense Universitaria, 1988); L. da Câmara Cascudo, Dicionário do Folclore Brasileiro (São Paulo: Global, 2000); S. Sàlámì (King), R.I. Ribeiro, Exu e a ordem do universe (São Paulo: Universidad de São Paulo, 2011; T. Gadacz and B. Milerski, eds., Religia. Encyklopedia PWN, Vol. 7 (Warsaw: Wydawnictwo PWN, 2003), 441; J. L. Matory, Black Atlantic Religion: Tradition, Transnationalism, and Matriarchy in the Afro-Brazilian Candomblé (Princeton, Princeton University Press, 2005).

J. Beniste, Òrun-Àiyè: O encontro de dois mundos (Rio de Janeiro: Bertrand; Edição, 1997), 83-84.

R.C. Abraham, Dictionary of Modern Yoruba (London: University of London Press, 1946), 172.

J. Elbein dos Santos, Os Nàgô e a morte, 70-71.

J. Beniste, Òrun-Àiyè, 79. 
the Supreme Being govern the world. ${ }^{29}$ They also connect a specific group of people with the Supreme God in whom they believe. ${ }^{30}$ Orishas Reliogiology are always linked to the daily lives of people belonging to a particular religious community, and they appear under certain circumstances such as ritual rites or festivals that take place in centers of worship. ${ }^{31}$

An extensive mythology associated with Orisha worship exists. In traditional African Yaruba societies, myths explain past, present, and future. The entire mythology of the Yaruba was orally transmitted from one generation to another. In Cuba, however, the babalawos-the highest priests of Ifá (the deity of wisdom)—kept the records of the prophecies called patakis, which contain sacred myths, interpretations, and predictions. ${ }^{32}$ These records were later used as source material for research on Cuban Santería. Contemporary scholars of Cuban Santería include Lydia Cabrera, Natalia Bolívar Aróstegui, Samuel Feijoo, and Rómulo Lachatañeré. ${ }^{33}$

\section{Orishas According to Nelson M. Aboy Domingo}

In contrast with the aforementioned interpretations Orishas in African and Afro-American religions, Nelson Marcos Aboy Domingo provides a very original approach to the nature of Orishas, their function, and their roles in Cuban Santería. ${ }^{34}$ In his description, Aboy Domingo

29 R.I.Ribeiro, Alma africana no Brasil. Os Iorubás (São Paulo: Editoria Oduduwa, 1996), 129; R. Prandi, Mitologia dos Orixás (São Paulo: Companhia das Letras, 2001), 20.

M. de Lourdes Siqueira, Agô, Agô Lonan. Mitos, Ritos e Organização em Terreiros de Candomblé da Bahia, (Brazil: Belo Horizonte 1998),42.

31 Ibid, 43

32 R. Prandi, Mitologia dos Orixás, 26-27.

33 L. Cabrera, Yemanjá y Ochún: kariocha, iyarorichas y olorichas, (Madrid: Ediciones Universal, 1974); N. Bolívar Aróstegui, Los Orichas en Cuba (Havana: Ediciones Unión,1990); S. Feijoo, Mitologia cubana (Havana: Letras Cubanas, 1986); R. Lachatañeré, Manual de Santeria (Havana: Editorial de Ciencias Sociales 1995).

34 Nelson Marcos Aboy Domingo was born in 1948 in Havana, Cuba. He is an anthropologist and works at the University of Havana's Department of History as well as at the Centro Nacional de Superación y Desarrollo Juan Marinello and the Fundación Fernando Ortiz. Since 1996, N.M. Aboy Domingo has been a member of Academy of Science of Cuba. He served for three years as the President of La Casa Museo de Africa, which is located at the City of Havana's Office for Historians. He is also a member of the following associations: Centro Cultural "Félix Varela," La Sociedad Cultural Yoruba de Cuba, and The National African Religion Congress located in Philadelphia. Aboy Domingo is the 
shows the religious phenomena of Orisha worship in Cuban Santería and carefully analyzes it from ethnopsychological, ethnobotanical, and anthropological points of view. ${ }^{35}$ Aboy Domingo believes that during the colonization of Cuba, the religious practice of "Orishas" worship resulted from the combination of religious performances and Catholic spiritual practices with non-religious, natural, energetic processes.

According to Aboy Domingo, "santería" is a term derived from Spanish that arose during the colonial period in Cuba. This term has a negative connotation that refers to all aspects of the worship of Orishas, which, in Cuban culture, are synonymous with the Catholic saints. ${ }^{36}$ Aboy Domingo concludes that the term "Orisha" derives from the Anago language of the ancient empire of Yoruba, where "Orí-" means "human head" 37 and "-isha" means "the deity, divine being." 38 The suffix "-isha" indicates human intelligence, which is the specific and unique element of each person. Using metaphorical language, Aboy Domingo defines "-isha" as "the inner supreme deity, which possesses human beings, [or] the inner highest being that creates man (human subjectivity)." ${ }^{39}$ Aboy Domingo states that, establishing a personal Orisha "is a way of establishing a personality archetype and its meaning, which corresponds with a specific element of nature (with similar physical and psychological vibration frequencies) as the result of the codification and interpretation of a person's energetic vibrations." ${ }^{0}$

recipient of many awards for research on culture, including Premio Ministerio de Cultura República de Angola (1999), Premio "Merceditas Valdés Inmemorían" Fundación Fernándo Ortiz (La Habana 1999), Premio Especial Embajada de Benín en Cuba (2000), and Premio Nacional "Memoria Viva" categoría de Personalidades Instituto Cubano de Investigación Cultural "Juan Marinello"(2009). Aboy Domingo has been conducting research for more than 30 years and is the author of many publications on the culture of the Bantu and Yoruba people in Cuba and in America as well as the history of initiation into orisha cults in Cuba. He wrote the book 25 Siglos de Historia de la Santería Cubana: Una Investigación antropológica desde el interior de sus prácticas cilturales (Spain EDITORES. S. A. Santander, 2004). Nelson M. Aboy Domingo has been an active babaláwo in Cuban Santería for more than 30 years. All of this information has been obtained from the archives of the author of this article.

N. M. Aboy Domingo, 25 Siglos de Historia de la Santería Cubana: Una Investigación antropológica desde el interior de sus prácticas cilturales (Spain: Editores. S. A. Santander, 2004).

Ibid, 151.

Ibid, 152.

Ibid, 122.

Ibid, 153.

Ibid, 99; author's own translation. 
In other words, an Orisha is a kind of primitive cultural element that, through the mediation of specific techniques and functions, aims to Reliogiology qualitatively identify our present reality: what and who we are as well as what we do in the sustainable world of nature. Orisha points to the essence of our "I" in relation to the world with which we are connected.

Determining one's own personal Orisha involves classifying the inherent frequency of energetic vibrations that always coincide with a specific process of personal fulfillment and respect for a specific natural energy. According to Aboy Domingo, "Osha" is the supremest "deity" of the human head, and, in the deepest sense, the temple that hosts the "deity." According to Aboy Domingo, the concept of Orisha is of two transcendent symbols that refer to the essence of man as a subject and an object. Due to an individual's personality, an Orisha is a non-transferable entity. Orisha is a thought that constantly acts subconsciously within the inner reality-within a number of numerically important social sectors (so-called "santeros") as the "cultural codex of the existence of something real inside of the heads of human beings that innately have the highest objectively human but subjectively mysterious qualities." 41

In this sense, an Orisha is to be understood as "the lead macroparticle that suits us. It is the psychosomatic genetic code that we possess. It is the part of us that lives according to the principle of conduct previously established for every human being. It is the entire section of our brain that directs the whole program contained in and created by it, for the sake of this archetypal and spatially characteristic personality." ${ }^{2}$ Hence, the Orisha is an individual identity, unique, particular, one's own, and unrepeatable. All of the congenital properties and human capacities inherited and determined by biology are found in the Orisha. All information relating to our existence is contained and expressed through the energy sent in a given Orisha. Thus the Orisha is not an ordinary being that exists as a philosophical or a theological concept. Our personal Orisha, says N.M. Aboy Domingo, "is our ideal main character, whom we know very well of and which we have to come to understand even better in our particular life. In addition, from a cultural point of view, worshiping our own Orisha helps us know the Orisha's role and involvement in our life; through this, we can identify the best way of life for us." 43

\footnotetext{
41 Ibid,154; author's own translation.

42 Ibid, 154; author's own translation.

43 Ibid, 155; author's own translation.
} 


\section{The Concept of Orisha Worship}

Orisha worship in Cuban Santería involves the practice of religious initiation, which, according to Aboy Domingo, has its own form. ${ }^{44}$ While still preserving and cultivating elements of the cultural identity of individual Orishas, the initiation process for one Orisha has evolved into a cult in honor of many Orishas. Thus, Orisha worship in Cuban Santería involves various elements of many cultures. Orisha worship is the first experience of identification and recognition, respect and competition, which expresses our own individual personality and our individual psychophysical identity by exploring our own character traits and the social environment in which we live. ${ }^{45}$ Aboy Domingo thus defines Orisha worship as "a cult by which we worship higher forms of intelligence as hidden energy not defined by the parts of the conscious and subconscious. Orisha worship is hidden energy located in the interior of our brain (in what the Yoruba call elegdá, or the cerebral cortex) in the form of vibrations." 46

Therefore, in Cuban Santería, Orisha worship is a cult aimed at honoring the individual personality that directs a person's life and, according to Aboy Domingo, the cult that is harnessed in the process of "realizing a person's genetic code." ${ }^{47}$ Orisha worship aims to help people accept their lives and everything that will happen in them; as such, it serves to properly orient human life and how people conduct themselves in certain socio-cultural circumstances. Nelson M. Aboy Domingo cites findings from people who have been initiated in Orisha worship..$^{48}$ Of the 256 people surveyed, $94 \%$ reported that they sought to be initiated into Orisha worship because of their own difficulties and health problems, while $6 \%$ reported that they sought initiation because of difficulties in their sociocultural environment. Based on

44

Ibid, 124.

Ibid. N.M. Aboy Domingo describes this in the following way: "Realmente las personas no son iniciadas al culto de los orishas en general, sino que son iniciadas a un orisha dentro del culto general de los orishas. Independientemente de adicionalmente recibir otros más por las razones antes expuestas. Lo cual demuestra el original culto a la personalidad individual."

Ibid, 156-157. This is the author's own translation. The original text states: "Es el culto que rendimos a formas superiores de la inteligencia del inconsciente humano, no supeditadas a los sectores del consciente y subconsciente; como una energía implícita que en forma de vibración se encuentra dentro de nuestro proprio cerebro, localizado en lo que denominan elegdá (la corteza cerebral)."

Ibid, 159.

Ibid, 160 . 
his understanding of Orisha worship, Aboy Domingo points out some of the problems of human spirituality ${ }^{49}$ Personal piety, as a particular Reliogiology profession of faith in a specific Orisha, has an individual dimension that is not a necessary condition for Orisha worship. A particular person's religious affiliation with Cuban Santería does not depend on his respect for or worship of his personal Orisha, but rather on his initiation into the cult of Ifá. According to Aboy Domingo, the primary aim of Orisha worship is to solve the personal, and ultimately existential, problems of individual people. As such, Orisha worship is emphasized more in the sociocultural dimension of life than in religion.

\section{Conclusion}

The concept of Cuban Santería presented in this article does not cover the whole of the subject matter and its interpretation which Nelson M. Aboy Domingo's interesting work describes. A different interpretation (from that commonly accepted in the field of the anthropology of religion) may be the starting point for further reflection on understanding the essence, function, and role of Orishas in African-American religions. Interpreting the concept of Orishas from biological, psychological, cultural, personality, and existential points of view, places the self-realization of man in his natural environment without reference to transcendental values. Certainly, Nelson M. Aboy Domingo's point of view is an essential element of the controversy surrounding the holistic understanding of the place and role of Orishas in the realm of African-American religions.

The concept of the Cuban Santería that this article presents sheds new light on the interpretation of religious syncretism and on understanding human salvation. According to Nelson M. Aboy Domingo, the elements of worship in Cuban Santería serve man's personal development in the temporal dimension. This point of view questions whether salvation exists in Cuban Santería. Bearing in mind the phenomenon of religious syncretism, as well as the acceptance and realization of the goals of salvation, ${ }^{50}$ it can be stated that Cuban Santeria worship according to Nelson M. Aboy Domingo does not include references to salvation and, therefore, does not transfer the essence of religious phenomena to the psychic realm of the human being.

49

50

Ibid, 172.

See: H. Waldenfels, ed., Leksykon religii. Zjawiska - dzieje - idee (Warsaw: Verbinum, 1997), 447. 


\section{ORISZE W SANTERII KUBAŃSKIEJ W UJĘCIU NELSONA MARCOSA ABOYA DOMINGO}

Santeria (określana także jako La Regla de Ocha) to synkretyczna religia afroamerykańska występująca na Kubie. Centrum tej religii stanowi wiara w Istotę Najwyższą, w bogów - pośredników (orisze) i duchy przodków. Orisze określa się jako bóstwa pośredniczące między Istotą Najwyższą a człowiekiem. Reprezentują one uosobienie sił przyrody oraz zjawisk naturalnych: narodziny i śmierć, zdrowie i chorobę, deszcz i rosę, drzewa i rzeki. Orisze przedstawiają cztery wielkie elementy natury: ogień, wodę, ziemię i powietrze, jak również trzy wymiary przyrody: mineralny, roślinny oraz zwierzęcy. Orisze stanowią emanację Istoty Najwyższej, od której otrzymały boskie atrybuty oraz charakterystykę, stąd też mają za zadanie pomoc Istocie Najwyższej w zarządzaniu światem. W niniejszym opracowaniu ukazano oryginalną koncepcję pojęcia "orisza" w ujęciu Nelsona Marcosa Aboya Domingo - kubańskiego antropologa i babaláwo. Na początku zarysowano proces kształtowania się pojęcia „orisza”. Następnie przedstawiono istotę, funkcję, rolę oriszów oraz ich kult w santerii kubańskiej według koncepcji kubańskiego antropologa.

Słowa kluczowe: Santeria kubańska, orisze, kult, bóstwa, religie afroamerykańskie, Nelson Marcos Aboy Domingo.

\section{Bibliography:}

1. Aboy Domingo N. M., 25 Siglos de Historia de la Santería Cubana: Una Investigación antropológica desde el interior de sus prácticas cilturales (Spain: Editores. S. A. Santander, 2004).

2. Abraham R. C., Dictionary of Modern Yoruba (London: University of London Press, 1946).

3. Bastide R., The African Religions of Brazil: Toward a Sociology of the Interpenetration of Civilizations, trans. H. Sebba (Baltimore: John Hopkins University Press, 1978).

4. Baudin N., Dictionnaire français-yoruba et yoruba-français, $2^{\text {nd }}$ Edition (Cotonou: 1967).

5. Beniste J., Òrun-Àiyè: O encontro de dois mundos (Rio de Janeiro: Bertrand; Edição, 1997).

6. Bolívar Aróstegui N., Los Orichas en Cuba (Havana: Ediciones Unión,1990).

7. Cabrera L., Yemanjá y Ochún: kariocha, iyarorichas y olorichas, (Madrid: Ediciones Universal, 1974).

8. Cacciatore O.G., Dicionário de cultos afro-brasileiros (Rio de Janeiro: Forense Universitaria, 1988).

9. Câmara Cascudo L. da, Dicionário do Folclore Brasileiro (São Paulo: Global, 2000).

10. Castellanos J. and Castellanos I., Cultura afrocubana, Vol. 1 (Miami: Ediciones Universal, 1988). 
11. Cohen C.L. and Numbers R.L., Eds., Gods in America: Religious Pluralism in the United States (New York: Oxford University Press, 2013).

12. Crowther S. J., A vocabulary of the yoruba language (London: Seeley, Fleet Street, 1852).

13. Curtin P. D., The Atlantic Slave Trade. A Census (Madison: University of Wisconsin Press 1969).

14. Desmangles L.G., The Faces of the Gods: Vodou and Roman Catholicism in Haiti (North Carolina: North Carolina U Press, 1992).

15. Elbein dos Santos J., "Pierre Verger e os resíduos coloniais: o ‘outro' fragmentado," Religião e Sociedade, no. 8 (Rio de Janeiro: ISER-CER, 1982).

16. Elbein dos Santos J., Os Nàgô e a morte. Pâde, Àsèsè e o culto Égun na Bahia, ${ }^{\text {th }}$ Edition (Petrópolis: 1997).

17. Ellis A. E., The Yoruba Speaking Peoples of the Slave Coast of West Africa: Their Religion, Manners, Customs, Laws, Language, Etc. (London: Chapman and Hall, 1894).

18. Feijoo S., Mitologia cubana (Havana: Letras Cubanas, 1986).

19. Gadacz T. and Milerski B., eds., "Santería," Religia. Encyklopedia PWN, Vol. 9 (Warsaw: Wydawnictwo PWN, 2003).

20. Gadacz T. and Milerski B., eds., Religia. Encyklopedia PWN, Vol. 7 (Warsaw: Wydawnictwo PWN, 2003).

21. Guanche J., "Las religiones afroamericanas en América Latína y el Caribe ante los desafíos de internet," in América Latína y el Caribe. Territórios religiosos y desafios para el diálogo, ed. Aurelio Alonso (Buenos Aires: CLASCO, 2008.

22. Matory Lorand J., Black Atlantic Religion: Tradition, Transnationalism, and Matriarchy in the Afro-Brazilian Candomblé (Princeton, Princeton University Press, 2005).

23. Lachatañeré R., Manual de Santeria (Havana: Editorial de Ciencias Sociales 1995).

24. Lourdes Siqueira M. de, Agô, Agô Lonan. Mitos, Ritos e Organização em Terreiros de Candomblé da Bahia, (Brazil: Belo Horizonte 1998).

25. Martins Terra J. E., "Sincretismo e cristianismo," Revista de Cultura Biblica Vol. 33, no. 34 (1985).

26. Pietrzak A., "Synkretyczne religie afrykańskie w Ameryce Łacińskiej," Dzieje kultury latynoamerykańskiej, ed., M.F. Gawrycki (Warsaw: Wydawnictwo PWN, 2009).

27. Piłaszewicz S., Religie Afryki (Warsaw: Wydawnictwa Uniwersytetu Warszawskiego, 2000).

28. Piłaszewicz S., Religie i mitologia Czarnej Afryki: Przeglad encyklopedyczny (Warsaw: Wydawnictwo Akademickie Dialog, 2002).

29. Prandi R., Mitologia dos Orixás (São Paulo: Companhia das Letras, 2001).

30. Ramos A., O negro brasileiro (São Paulo: 1940).

31. Ribeiro R. I., Alma africana no Brasil. Os Iorubás (São Paulo: Editoria Oduduwa, 1996).

32. Rodrigues N., Os Africanos no Brasil (Rio de Janeiro, 1934).

33. Sàlámì S. (King), Ribeiro R.Y., Exu e a ordem do universe (São Paulo: Universidad de São Paulo, 2011). 
34. Verger P., "Etnografia religiosa iorubá e probidade científica," Religião e Sociedade, no. 8 (Rio de Janeiro: 1982).

35. Verger P., Notas sobre o culto aos orixas e voduns na Bahia de Todos os Santos, no Brasil, e na antiga Costa dos Escravos, na África (São Paulo: EDUSP, 1999).

36. Verger P., Notas sobre o culto aos orixás e voduns na Bahia de Todos os Santos, no Brasil, e na antiga Costa dos Escravos, na África, trans. C. E. Marcondes de Moura (São Paulo: Editora da Universidade de São Paulo, 1999).

37. Verger P., Notes sur le culte des orixá (Dacar: 1957).

38. Waldenfels H., ed., Leksykon religii. Zjawiska - dzieje - idee (Warsaw: Verbinum, 1997). 